\title{
Effects of a dietary added formaldehyde-propionic acid blend on feed enterobacteria counts and on growing pig performance and fecal formaldehyde excretion
}

\author{
Efeitos da adição de uma mistura de formaldeído e ácido propiônico \\ na dieta sobre a contagem de enterobactérias na ração e \\ sobre o desempenho e excreção fecal de formaldeído de suínos em crescimento
}

\author{
Maicon Sbardella ${ }^{I^{*}}$ Danilo do Prado Perina ${ }^{I}$ Carla de Andrade ${ }^{I}$ \\ Flavio Alves Longo II Valdomiro Shigueru Miyada ${ }^{I}$
}

\begin{abstract}
The purpose of this study was to evaluate the effects of a dietary added formaldehyde-propionic acid blend on feed enterobacteria counts and on growing pig performance and fecal formaldehyde excretion. Forty pigs $(34.2 \pm 1.8 \mathrm{~kg} \mathrm{BW})$ were used in a randomized complete block design experiment with four treatments, five replications per treatment and two animals per experimental unit (pen). The treatments were: 0.0, 1.0, 2.0, and $3.0 \mathrm{~g}$ of blend $\mathrm{kg}^{-1}$ of feed. No effects $(P>0.05)$ of dietary added blend levels were observed on average daily gain, average daily feed intake and feed:gain ratio during 1 to 14 and 1 to 28 days of experiment. Increasing dietary levels of blend reduced quadratically $(P<0.01)$ total Enterobacteriaceae counts on $1^{\text {st }}$ and $14^{\text {th }}$ day after feed mixing, allowing to estimate, respectively, 2.63 and $3.35 \mathrm{~g} \mathrm{~kg}^{-1}$ (average 2.99 $\mathrm{kg}^{-1}$ ) as the formaldehydepropionic acid blend levels with lowest feed Enterobacteriaceae counts. Therefore, formaldehyde-propionic acid blend can reduce and/or control feed Enterobacteriaceae growth. There was no effect $(P>0.05)$ of blend on fecal formaldehyde excretion on the $28^{\text {th }}$ day of the experimental period. Therefore, the addition of dietary formaldehyde-propionic acid blend up to $3.0 \mathrm{~g} \mathrm{~kg}^{-1}$ of feed reduces the Enterobacteriaceae counts until the $14^{\text {th }}$ day after feed mixing, without any effects on growing pig performance and fecal formaldehyde excretion.
\end{abstract}

Key words: feed additive, Enterobacteriaceae, swine.

\section{RESUMO}

O objetivo deste estudo foi avaliar os feitos de um blend de formaldeido e ácido propiônico em dietas para suinos em crescimento sobre a contagem de enterobactérias na ração armazenada, o desempenho zootécnico e a excreção fecal de formaldeído. Quarenta suinos (34,2 $\pm 1,8 \mathrm{~kg}$ de peso vivo) foram utilizados em um experimento em blocos completos casualizados, com quatro tratamentos, cinco repetições por tratamento e dois animais por unidade experimental (baia). Os tratamentos foram:
0,0, 1,0, 2,0 e 3,0g de blend $\mathrm{kg}^{-1}$ de ração. Não foram observados efeitos $(P>0,05)$ dos niveis de blend sobre o ganho diário de peso, consumo diário de ração e conversão alimentar durante os periodos 1 a 14 e 1 a 28 dias de experimento. O aumento dos niveis de blend na dieta reduziu quadraticamente $(P<0,01)$ a contagem total de Enterobacteriaceae no 1o e 14음 dias após a fabricação das dietas, sendo estimados, respectivamente, 2,63 e 3,35g $\mathrm{kg}^{-1}$ (média 2,99 $\mathrm{g} \mathrm{kg}^{-1}$ ) como os níveis do blend de formaldeído e ácido propiônico com as menores contagens de Enterobacteriaceae na ração. Portanto, o blend de formaldeido e ácido propionico pode reduzir elou controlar o crescimento de Enterobacteriaceae na ração. Não houve efeito $(P>0,05)$ do blend sobre a excreção fecal de formaldeído no dia 28 do periodo experimental. Portanto, a inclusão de um blend de formaldeído e ácido propiônico até o nível de 3,0 $\mathrm{g} \mathrm{kg}^{-1}$ de ração reduz a contaminação de Enterobacteriaceae até 14 dias após a fabricação da ração, sem quaisquer efeitos sobre o desempenho e a excreção fecal de formaldeido.

Palavras-chave: aditivo tecnológico conservante, Enterobacteriaceae, suíno.

\section{INTRODUCTION}

The feed contamination of Enterobacteriaceae, mainly Salmonella sp., is one of great concern in commercial swine production, because it can be an important vehicle of pathogens to animals and humans (DAVIES \& HILTON, 2000; KORSAK et al., 2003; MACIOROWSKI et al., 2006). In addition, the contamination of feed mills and feeding systems, especially in non-accessible areas, may be sources of feed and animal contamination (FURUTA et al., 1980; TORROELLA et al., 1987). Subclinical

'Departamento de Zootecnia, Escola Superior de Agricultura “Luiz de Queiroz” (ESALQ), Universidade de São Paulo (USP), CP 09, 13418-900, Piracicaba, SP, Brasil. E-mail: msbardella@gmail.com. *Corresponding author.

"Departamento de Pesquisa e Desenvolvimento, Btech Tecnologias Agropecuárias e Comércio Ltda (BTECH), Valinhos, SP, Brasil. 
effects of pathogenic Enterobacteriaceae on weaned pigs are difficult to quantify, but their performance has been improved when the contamination of feed was lowered (DeROUCHEY et al., 2004). However, there are studies suggesting a potential link between the microorganisms in feed and microorganisms causing human and animal diseases, which may be a food safety problem (DAVIES \& HILTON, 2000; KORSAK et al., 2003; MACIOROWSKI et al., 2006; EFSA, 2008). Thus, the availability of additives that can control recontamination of feed with potential pathogens is essential to the safety of food for animals.

Chemical products, such as formaldehydebased feed additives, can help to decrease and/ or prevent bacterial contamination in feed stuffs (KAISER, 1992; ANDERSON et al., 2001). Formaldehyde has been shown to have antimicrobial activity when added to animal feeds, and have been used as feed additive especially to control Salmonella sp. (MOLLER, 1983; MOUSTAFA et al., 2002). Blends of formaldehyde, propionic acid and other dispersing agents have been shown to achieve greater decontamination of inoculated feed with Salmonella sp. compared to several acid products (CARRIQUE-MAS et al., 2007). However, high levels of formaldehyde in the feed may affect the palatability of diets for pigs (PATTERSON et al., 1989; LY et al., 2000) and reduce feed intake (SCAN, 2002; EFSA, 2008).

The purpose of this study was to evaluate the effects of a dietary added formaldehyde-propionic acid blend on feed enterobacteria counts and on growing pig performance and fecal formaldehyde excretion.

\section{MATERIAL AND METHODS}

Forty crossbred growing pigs of a commercial genetic line named Topigs ${ }^{\circledR}$ were used in a randomized complete block (based on gender and initial BW) design experiment, with four treatments, five replications per treatment and two animals per experimental unit (pen). A barrow and a gilt were housed in $1.2 \times 2.9 \mathrm{~m}$ pens with partially slatted floors from $34.16 \pm 1.80 \mathrm{~kg}$ to $61.08 \pm 2.76 \mathrm{~kg}$ body weight (BW) in a naturally ventilated building. Feed and water were provided ad libitum to the pigs during the 28 days of experimental period.

The treatments consisted of four dietary levels of a formaldehyde-propionic acid blend: 0 (control), 1.0, 2.0, and $3.0 \mathrm{~g}$ of blend $\mathrm{kg}^{-1}$ of feed. The formaldehyde-propionic acid blend was a commercial liquid product $\left(\right.$ Salmex $^{\circledR}$, trade mark of Btech Tecnologias Agropecuárias e Comércio Ltda) composed by $33 \%$ formaldehyde, $9 \%$ propionic acid, terpenes and surfactants, and was applied using liquid aspersion equipment to guarantee dosage and homogeneity of the production the feed.

A two-phase feeding program was formulated according to the nutrient requirements for growing pigs (ROSTAGNO et al., 2005): grower 1 diet (from 1 to $14 \mathrm{~d}$ of experiment) and grower 2 diet (from 15to 28d of experiment) (Table 1). Corn-soybean meal basal diets were mixed using recommended standard feed manufacturing method (feedstuffs batch, package, and storage conditions) a day before starting each phase-feeding period. Average daily gain, average daily feed intake, and feed:gain ratio were calculated for each pen during 1 to $14^{\text {th }}$ and 1 to 28 days of experiment. Feed samples were collected on the $1^{\text {st }}, 7^{\text {th }}$ and $14^{\text {th }}$ days after feed mixing for analysis of the blend recovery in the feed

Table 1 - Composition of the experimental diets (as-fed basis).

\begin{tabular}{|c|c|c|}
\hline \multirow{2}{*}{ Ingredient } & \multicolumn{2}{|c|}{-------- Diet --------- } \\
\hline & Grower 1 & Grower 2 \\
\hline Corn, $\mathrm{g} \mathrm{kg}^{-1}$ & 758.2 & 770.2 \\
\hline Soybean meal (46\%), $\mathrm{g} \mathrm{kg}^{-1}$ & 204.7 & 202.9 \\
\hline Dicalcium phosphate, $\mathrm{g} \mathrm{kg}^{-1}$ & 12.6 & 9.9 \\
\hline Limestone, $\mathrm{g} \mathrm{kg}^{-1}$ & 6.5 & 6.1 \\
\hline Salt, $\mathrm{g} \mathrm{kg}^{-1}$ & 3.6 & 5.0 \\
\hline Spray-dried plasma, $\mathrm{g} \mathrm{kg}^{-1}$ & 5.1 & - \\
\hline L-Lysine. $\mathrm{HCl}(78 \%), \mathrm{g} \mathrm{kg}^{-1}$ & 4.6 & 2.8 \\
\hline DL-Methionine (99\%), $\mathrm{g} \mathrm{kg}^{-1}$ & 1.4 & 0.5 \\
\hline L-Threonine (98.5\%), $\mathrm{g} \mathrm{kg}^{-1}$ & 1.1 & 0.6 \\
\hline L-Tryptophan (98\%), $\mathrm{g} \mathrm{kg}^{-1}$ & 0.1 & - \\
\hline Trace mineral premix ${ }^{1}, \mathrm{~g} \mathrm{~kg}^{-1}$ & 1.0 & 1.0 \\
\hline Vitamin premix ${ }^{2}, \mathrm{~g} \mathrm{~kg}^{-1}$ & 1.0 & 1.0 \\
\hline \multicolumn{3}{|l|}{ Calculated values: } \\
\hline Metabolizable energy, $\mathrm{kcal} \mathrm{kg}^{-1}$ & 3,230 & 3,230 \\
\hline Crude protein, $\mathrm{g} \mathrm{kg}^{-1}$ & 164.8 & 158.7 \\
\hline Calcium, $\mathrm{g} \mathrm{kg}^{-1}$ & 6.3 & 5.5 \\
\hline Total phosphorus, $\mathrm{g} \mathrm{kg}^{-1}$ & 5.2 & 4.8 \\
\hline Available phosphorus, $\mathrm{g} \mathrm{kg}^{-1}$ & 3.3 & 2.8 \\
\hline Digestible lysine, $\mathrm{g} \mathrm{kg}^{-1}$ & 10.5 & 8.8 \\
\hline Digestible methionine, $\mathrm{g} \mathrm{kg}^{-1}$ & 3.7 & 2.8 \\
\hline Digestible met+cys, $\mathrm{g} \mathrm{kg}^{-1}$ & 6.3 & 5.3 \\
\hline Digestible tryptophan, $\mathrm{g} \mathrm{kg}^{-1}$ & 1.8 & 1.6 \\
\hline Digestible threonine, $\mathrm{g} \mathrm{kg}^{-1}$ & 6.4 & 5.7 \\
\hline
\end{tabular}

${ }^{1}$ Provided per kilogram of feed: manganese, $60 \mathrm{mg}$; zinc, $150 \mathrm{mg}$; iron, 100mg; copper, 10mg; iodine, $1.2 \mathrm{mg}$.

${ }^{2}$ Provided per kilogram of feed: vitamin A, 11,500UI; vitamin $\mathrm{D}_{3}$, $5,850 \mathrm{UI}$; vitamin E, 45UI; vitamin $\mathrm{K}_{3}, 3 \mathrm{mg}$; thiamine, $1.8 \mathrm{mg}$; riboflavin, $5.1 \mathrm{mg}$; pyridoxine, $3.5 \mathrm{mg}$; vitamin $\mathrm{B}_{12}, 24 \mu \mathrm{g}$; folic acid, $0.82 \mathrm{mg}$; pantothenic acid, $18 \mathrm{mg}$; niacin, $37.5 \mathrm{mg}$; biotin, $0.14 \mathrm{mg}$; selenium, $0.35 \mathrm{mg}$; ethoxyquin, $0.042 \mathrm{mg}$. 
for treatment confirmation, and on the $1^{\text {st }}$ and $14^{\text {th }} d$ for analysis of total Enterobacteriaceae counts in the feed. At the $28^{\text {th }}$ day of the experimental period, feces samples were collected directly from the rectum of animals for formaldehyde quantification. The analysis of blend recovery in the diet and formaldehyde quantification in the feces was based on formaldehyde quantification using high-performance liquid chromatography (HPLC) (AOAC, 2005). For total Enterobacteriaceae counts, feed samples were diluted and transferred to the cultivation media of violet red bile agar with glucose (VRBG) to the selective isolation and identification of Enterobacteriaceae genus, and results were expressed as CFU (colonyforming unit) $\mathrm{g}^{-1}$ (MAPA, 2003).

Data were analyzed using the MIXED procedure of SAS ${ }^{\circledR}$ (SAS Institute Inc., Cary, North Carolina, USA). The model for pig performance and formaldehyde in the feces data analysis included the fixed effects of the dietary blend levels and the random effect of block, as follows:

$Y(i j)=\mu+t(i)+b(j)+\varepsilon(i j)$, where:

$Y(i j)$ is the dependent response, $\mu$ is the overall mean, $t(i)$ is the fixed effect of dietary blend levels $(i=0, \ldots 3), b(j)$ is the random effect of block $(j$ $=1, \ldots 5)$ and $\varepsilon(i j)$ is the experimental error.

Concerning total Enterobacteriaceae counts, data were transformed using the $\log _{10}$ function to run the statistical analysis. The model for analysis of total Enterobacteriaceae counts and blend recovery data included the fixed effects of dietary blend levels and time:
$Y(i j)=\mu+t(i)+p(j)+t^{*} p(i j)+\varepsilon(i j)$, where:

$Y(i j)$ is the dependent response, $\mu$ is the overall mean, $t(i)$ is the fixed effect of dietary blend levels $(i=0, \ldots 3), p(j)$ is the fixed effect of time (total Enterobacteriaceae counts: $j=1,2$; blend recovery: $j=$ $0, \ldots 3), t^{*} p(i j)$ is the interaction between dietary blend levels and time, and $\varepsilon(i j)$ is the experimental error.

The relationship between the dietary blend levels and the total Enterobacteriaceae counts was determined using polynomial regression analysis.

\section{RESULTS AND DISCUSSION}

The pigs remained healthy throughout the trial and with no feed intake problems due to the added blend of formaldehyde and propionic acid.

No effects $(\mathrm{P}>0.05)$ of dietary formaldehyde-propionic acid blend levels were observed on average daily gain, average daily feed intake or feed:gain ratio of the growing pigs (Table 2). These results are an indication that formaldehydebased additives may be used in corn-soybean meal diets for growing pigs as a way of decontamination of feed, feed mills and feeding systems, without affecting feed intake and pig performance. Beneficial effects of formaldehyde-based feed additive on pigs performance have been shown when feed is formulated with ingredients susceptible to high microbial degradation, such as meat and bone meal, spray-dried plasma (DeROUCHEY et al., 2004) and syrup (LY et al., 2000). For example, nursery pigs (6 to $10 \mathrm{~kg} \mathrm{BW}$ ) fed with formaldehyde-treated plasma

Table 2 - Effects of dietary levels of a formaldehyde-propionic acid blend on body weight (BW), average daily gain (ADG), average daily feed intake (ADFI), feed:gain ratio and formaldehyde excretion in the feces of growing pigs.

\begin{tabular}{|c|c|c|c|c|c|c|}
\hline \multirow{2}{*}{ Item } & \multicolumn{6}{|c|}{ 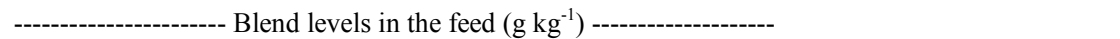 } \\
\hline & 0.0 & 1.0 & 2.0 & 3.0 & & \\
\hline Initial BW, kg & 33.94 & 34.16 & 34.08 & 34.45 & 1.80 & - \\
\hline $\mathrm{BW}, \mathrm{kg}$ & 46.81 & 47.19 & 46.97 & 46.16 & 2.30 & 0.787 \\
\hline ADG, $\mathrm{g} \mathrm{d}^{-1}$ & 919 & 931 & 921 & 836 & 56 & 0.560 \\
\hline ADFI, $\mathrm{g} \mathrm{d}^{-1}$ & 2,079 & 2,175 & 2,029 & 1,956 & 144 & 0.449 \\
\hline Feed:gain ratio & 2.25 & 2.35 & 2.22 & 2.33 & 0.09 & 0.631 \\
\hline $\mathrm{BW}, \mathrm{kg}$ & 59.52 & 61.61 & 61.45 & 60.18 & 2.76 & 0.548 \\
\hline $\mathrm{ADG}, \mathrm{g} \mathrm{d}^{-1}$ & 914 & 980 & 977 & 919 & 47 & 0.550 \\
\hline ADFI, $\mathrm{g} \mathrm{d}^{-1}$ & 2,251 & 2,395 & 2,276 & 2,232 & 139 & 0.658 \\
\hline Feed:gain ratio & 2.45 & 2.44 & 2.34 & 2.42 & 0.07 & 0.446 \\
\hline Fecal formaldehyde, $\mathrm{mg} \mathrm{kg}^{-1}$ & 0.15 & 0.18 & 0.19 & 0.19 & 0.02 & 0.440 \\
\hline
\end{tabular}

${ }^{1}$ Standard error of the mean. 
had improved performance compared to those fed diets with untreated plasma (DeROUCHEY et al., 2004). In addition, finishing pig (50 to $90 \mathrm{~kg}$ BW) fed with formaldehyde-treated syrup, a by-product of raw sugar refining, had improved feed intake and weight gain when compared to those fed with untreated syrup, without any effects of formaldehyde-treatment on dry matter and organic matter digestibility, and nitrogen and energy retention (LY et al., 2000). These are indication that higher microbial challenge and fermentation rate might have occurred in untreated feed stuffs and depressed its palatability.

No effects $(\mathrm{P}>0.05)$ of the dietary formaldehyde-propionic acid blend levels were observed on the formaldehyde fecal excretion on the $28^{\text {th }}$ day of experiment (Table 2). These results could be an indication that formaldehyde may have been degraded in the gastrointestinal tract. However, the results of this study were different from others. In a trial with growing pigs (20 to $30 \mathrm{~kg} \mathrm{BW}$ ) that had received feed treated with variable amounts of formaldehyde (from 0 to $990 \mathrm{mg} \mathrm{kg}^{-1}$ ) for six weeks, a dose dependent correlation with the fecal formaldehyde content (from 0.35 to $4.43 \mathrm{mg} \mathrm{kg}^{-1}$ ) was observed (SCAN, 2002). In addition, in two other experiments reported in the SCAN (2002) dossier, pigs fed with diets with or without formaldehyde ( 0 vs. $660 \mathrm{mg}$ of formaldehyde $\mathrm{kg}^{-1}$ ) showed higher concentrations of fecal formaldehyde $(0.07 \mathrm{vs}$. $0.34 \mathrm{mg} \mathrm{kg}^{-1}$, respectively), but the effect was lower than in the first study.

No interaction $(\mathrm{P}>0.05)$ between the dietary formaldehyde-propionic acid blend levels and storage time was observed on total
Enterobacteriaceae counts in the feed. However, increasing the dietary formaldehyde-propionic acid blend levels reduced quadratically $(\mathrm{P}<0.01)$ total Enterobacteriaceae counts on the $1^{\text {st }}$ and $14^{\text {th }}$ day after feed mixing (Table 3), allowing to estimate, respectively, 2.63 and $3.35 \mathrm{~g} \mathrm{~kg}^{-1}$ (average $2.99 \mathrm{~g} \mathrm{~kg}^{-1}$ ) as the formaldehyde-propionic acid blend levels with lowest feed Enterobacteriaceae counts. Therefore, formaldehyde-propionic acid blend can reduce and/ or control Enterobacteriaceae growth in the feed. The reduction of Enterobacteriaceae in the feed showed the bactericidal and/or bacteriostatic effects of formaldehyde-propionic acid blend in the period of $14 \mathrm{~d}$ after feed mixing.

An interaction $(\mathrm{P}<0.01)$ of the dietary formaldehyde-propionic acid blend levels and storage time was observed on blend recovery from the feed. When high dietary levels of blend (2.0 and $3.0 \mathrm{~g}$ of blend $\mathrm{kg}^{-1}$ of feed) were used, the main losses of formaldehyde were greater between 1 to $7 \mathrm{~d}$ after feed mixing, while in low dietary level $\left(1.0 \mathrm{~g}\right.$ of blend $\mathrm{kg}^{-1}$ of feed) the main loss occurred from 7 to $14 \mathrm{~d}$ of storage (Table 3). These losses may be due to formaldehyde reaction with amino acids, that can decrease the bacteriostatic effect (NITSCHMAN \& HADORN, 1941), or due to volatilization of formaldehyde (DAVID et al., 1972; KHAN et al., 2003). Even the security of the use of formaldehyde-based products as feed additive to farm animals have been discussed previously by the scientific community and believed to be safe (SCAN, 2002), formaldehyde-based feed additives has shown adverse histopathological effects on tissues when higher dosages and long-time exposure were provided

Table 3 - Effects of dietary levels of a formaldehyde-propionic acid blend on total Enterobacteriaceae counts in the feed on the $1^{\text {st }}$ and $14^{\text {th }}$ day after feed mixing and blend recovery in the feed on the $1^{\text {st }}, 7^{\text {th }}$ and $14^{\text {th }}$ day after feed mixing.

\begin{tabular}{|c|c|c|c|c|c|c|c|c|}
\hline \multirow{2}{*}{ Item } & \multicolumn{4}{|c|}{ 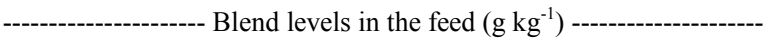 } & \multirow{2}{*}{ SEM $^{1}$} & \multicolumn{3}{|c|}{ - P value ----------------- } \\
\hline & 0.0 & 1.0 & 2.0 & 3.0 & & Blend & Time & Interaction \\
\hline \multicolumn{9}{|c|}{ 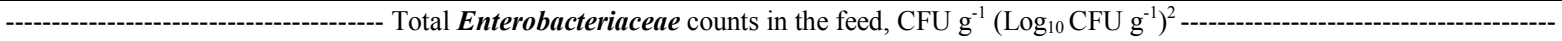 } \\
\hline $1^{\text {st }} d^{3}$ & $6290(3.35) \mathrm{a}$ & $868(2.20) \mathrm{b}$ & $148(1.66) b$ & $148(1.55) \mathrm{b}$ & 0.26 & \multirow{2}{*}{$<0.01$} & \multirow{2}{*}{0.089} & \multirow{2}{*}{0.735} \\
\hline $14^{\text {th }} d^{4}$ & $7590(3.33) \mathrm{a}$ & $1372(2.57) \mathrm{b}$ & $449(2.30) \mathrm{b}$ & $547(2.00) \mathrm{b}$ & 0.33 & & & \\
\hline & & & $\mathrm{d}$ recovery in & feed, $g$ of blen & of feed & & & \\
\hline $1^{\text {st }} \mathrm{d}$ & $0.00 \mathrm{a}$ & $1.12 \mathrm{bB}$ & $1.83 \mathrm{cA}$ & $2.95 \mathrm{Da}$ & 0.07 & \multirow{3}{*}{$<0.01$} & \multirow{3}{*}{$<0.01$} & \multirow{3}{*}{$<0.01$} \\
\hline $7^{\text {th }} \mathrm{d}$ & $0.00 \mathrm{a}$ & $1.14 \mathrm{bA}$ & $1.35 \mathrm{cB}$ & $1.85 \mathrm{~dB}$ & 0.09 & & & \\
\hline $14^{\text {th }} \mathrm{d}$ & $0.00 \mathrm{a}$ & $0.86 \mathrm{bC}$ & $1.36 \mathrm{cB}$ & $1.86 \mathrm{~dB}$ & 0.09 & & & \\
\hline
\end{tabular}

${ }^{1}$ Standard error of the mean; Different small letters in line differ $(\mathrm{P}<0.05)$, and different capital letters in columns differ $(\mathrm{P}<0.05)$.

${ }^{2} \mathrm{CFU}$ : Colony-forming unit.

${ }^{3}$ Quadratic effect of a blend on $1^{\text {st }}$ day Enterobacteriaceae counts: $Y=0.26 \mathrm{x}^{2}-1.37 \mathrm{X}+3.34 ; \mathrm{R}^{2}=0.999$

${ }^{4}$ Quadratic effect of a blend on $14{ }^{\text {st }}$ day Enterobacteriaceae counts: $Y=0.115 \mathrm{x}^{2}-0.771 \mathrm{x}+3.304 ; \mathrm{R}^{2}=0.986$.

Ciência Rural, v.45, n.3, mar, 2015. 
to White Leghorn cockerels (KHAN et al., 2003). Thus, to further estimate the safety of dietary formaldehydebased products in pigs and meat products for humans, analysis of effect on gut bacteria and histological experiments using pigs are highly required.

\section{CONCLUSION}

The use of a dietary formaldehydepropionic acid blend up to $3.0 \mathrm{~g} \mathrm{~kg}^{-1}$ of feed reduces the Enterobacteriaceae counts in the feed until 14d after feed mixing, without any effects on growing pig performance and fecal formaldehyde excretion.

\section{ACKNOWLEDGEMENTS}

We acknowledge the "Fundação de Estudos Agrários Luiz de Queiroz (FEALQ)" and "Btech Tecnologias Agropecuárias e Comércio Ltda" for granting aid for this research.

\section{CONFLICT OF INTEREST}

The authors declare that there is no conflict of interests concerning the publication of this article.

\section{ETHICS COMITTE AND BIOSECURITY}

The authors declare that this project was not submitted for evaluation to the "Committee of Ethics for the Use of Animals - CEUA/ESALQ/USP", but are aware of the resolutions of the "National Council for the Control of Animal Experimentation - CONCEA" < http://www.mct.gov.br/index.php/ content/view/310553.html $>$ and assume full responsibility for the presented data, as well as are available for possible questioning that should be required.

\section{REFERENCES}

ANDERSON, K.E. et al. Effect of termin-8 compound on the growth of commercial white and brown egg type pullets and environmental microbiological populations. Poultry Science, v.80, n.1, p.88, 2001. Available from: <http://eurekamag.com/ research/034/788/034788206.php>. Accessed: Aug. 29, 2014.

ASSOCIATION OF OFFICIAL ANALYTICAL CHEMISTRY (AOAC). Official methods of analysis. 18.ed. Gaithersburg, 2005. 2500p.

CARRIQUE-MAS, J.J. et al. Organic acid and formaldehyde treatment of animal feeds to control Salmonella: efficacy and masking during culture. Journal of Applied Microbiology, v.103, n.1, p.88-96, 2007. Available from: <http://onlinelibrary.wiley. com/doi/10.1111/j.1365-2672.2006.03233.x/abstract;jsessionid=0 22DD48A61C82CE8C9D1C5D4DDF9CF5F.f02t04>. Accessed: Nov. 20, 2013. doi: 10.1111/j.1365-2672.2006.03233.x.

DAVID, W.A.L. et al. The fumigant action of formaldehyde incorporated in a semi-synthetic diet on the granulosis virus of Pierisbrassicae and its evaporation from the diet. Journal of Invertebrate Pathology, v.19, n.1, p.76-82, 1972. Available from: <http://www.sciencedirect.com/science/ article/pii/0022201172901929>. Accessed: Nov. 20, 2013. doi: 10.1016/0022-2011(72)90192-9.

DAVIES, R.H.; HILTON, M.H. Salmonella in animal feed. In: WRAY, C.; WRAY, A. (Ed.). Salmonella in domestic animals. New York: CABI Publishing, 2000. p.285-300.

DeROUCHEY, J.M. et al. Evaluation of methods to reduce bacteria concentrations in spray-dried animal plasma and its effects on nursery pig performance. Journal of Animal Science, v.82, p. 250261, 2004. Available from: <http://www.journalofanimalscience. org/content/82/1/250.long>. Accessed: Nov. 20, 2013.

EUROPEAN FOOD SAFETY AUTHORITY (EFSA). Microbiological risk assessment in feeding stuffs for foodproducing animals. EFSA Journal, v.720, p.1-84, 2008. Available from: <http://www.efsa.europa.eu/en/efsajournal/pub/720.htm>. Accessed: Nov. 20 2013. doi: 10.2903/j.efsa.2008.720.

FURUTA, K. et al. Bacterial contamination in feed ingredients, formulated chicken feed and reduction of viable bacteria by pelleting. Laboratory Animals, v.14, p.221-224, 1980. Available from: <http://lan.sagepub.com/content/14/3/221>. Accessed: Nov. 20, 2013. doi: 10.1258/002367780780937463.

KAISER, S. The use of Salmex ${ }^{\circledR}$ in the control of Salmonella in fishmeal. St. Albans, Herefordshire, United Kingdom: International Association of Fishmeal Manufacturers, 1992. (Research Report 4).

KHAN, M.Z. et al.Pathological effects of formalin $(37 \%$ formaldehyde) mixed in feed or administered into the crops of White Leghorn cockerels. Journal of Veterinary Medicine Series A: Physiology, Pathology, Clinical Medicine, v.50, p.354-358, 2003. Available from: < http://onlinelibrary.wiley.com/ doi/10.1046/j.1439-0442.2003.00550.x/abstract>. Accessed: Nov. 20, 2013. doi: 10.1046/j.1439-0442.2003.00550.x.

KORSAK, N. et al. Salmonella contamination of pigs and pork in an integrated pig production system. Journal of Food Protection, v.66, n.7, p.1126-1133, 2003. Available from: <http://www. ingentaconnect.com/content/iafp/jfp/2003/00000066/00000007/art0 0002 ? token $=004 \mathrm{c} 1208206 \mathrm{e} 5865462431516 \mathrm{f} 5720675 \mathrm{~d} 7 \mathrm{a} 783 \mathrm{~b} 5 \mathrm{f5} 3$ 5e4e26634a492f2530332976cc8b7d9a>. Accessed: Nov. 20, 2013.

LY, J. et al. Formaldehyde protection of syrup off based diets for pigs: feeding value and nutrient utilization. Archivos Latinoamericanos de Produccion Animal, v.8, n.2, p.47-50, 2000. Available from: <http://www.alpa.org.ve/PDF/Arch $\% 20$ 08-2/AL\%20082-47.pdf>. Accessed: Aug. 29, 2014.

MACIOROWSKI, K.G. et al. Cultural and immunological detection methods for Salmonella spp. in animal feeds - A review. Veterinary Research Communications, v.30, p.127-137, 2006. Available from: <http://link.springer.com/article/10.1007\%2 Fs11259-006-3221-8>. Accessed: Nov. 20, 2013. doi: 10.1007/ s11259-006-3221-8.

MINISTÉRIO DA AGRICULTURA, PECUÁRIA E ABASTECIMENTO (MAPA). Instrução Normativa n.62, de 26 ago. 2003/MAPA: Oficializar os Métodos Analíticos Oficiais para Análises Microbiológicas para Controle de Produtos de Origem Animal e Água. Diário Oficial da União, Brasília, DF, 2003. Available from: <http://sistemasweb.agricultura.gov.br/sislegis/ action/detalhaAto.do?method=consultarLegislacaoFederal $>$. Accessed: Aug. 29, 2014. 
MOLLER, J. Treating feeds with formaldehyde to protect protein. Feedstuffs, v.30, p.12-13, 1983.

MOUSTAFA, G.Z. et al. Hygienic control of Salmonella in artificially contaminated feed. Veterinary Medical Journal Giza, v.50, n.2, p.239-246, 2002. Available from: <http://eurekamag. com/research/003/799/003799332.php>. Accessed: Aug. 29, 2014

NITSCHMAN, H.; HADORN, H. Method for the determination of formaldehyde in formalin-hardened casein. Helvetica Chimica Acta, v.24, p.237-242, 1941.

PATTERSON, M. et al. Empleo del formaldehido como un preservante de desperdicios procesados. Ciencia y Técnica en la Agricultura: Ganado Porcino, v.12, n.1, p.41, 1989.
ROSTAGNO, H.S. et al. Brazilian tables for poultry and swine: composition of feedstuffs and nutritional requirements. 2.ed. Viçosa: Universidade Federal de Viçosa, 2005. 186p.

SCIENTIFIC COMMITTEE FOR ANIMAL NUTRITION (SCAN). Update of the opinion of the Scientific Committee for Animal Nutrition on the use of formaldehyde as a preserving agent for animal feeding stuffs of 11 June 1999. Scientific Committee for Animal Nutrition, Brussels, Belgium, 2002. 19p. Available from: <http://ec.europa.eu/ food/fs/sc/scan/out95en.pdf $>$. Accessed: Mar. 09, 2011.

TORROELLA, E. et al. Assessment of the disinfection of feed silos with $2 \%$ formalin in poultry farms. Ciencia y Tecnica en la Agricultura Veterinaria, v.9, n.2, p.15-20, 1987. 